である。このトラブル回避により成果は数百 $\mathrm{kWh} / \mathrm{t}$ におよんで いる。今後, コンピュータによる多量のデータ採取と解析の容易 性から新しい制御方式が生まれてくる可能性は大きく，ゼーダへ ルグ型陽極の管理やアルミナのスラリー化防止の抜本詨策等が期 待できる。

以上の省エネルギー化の探求により, ゼーダベルグ型電解槽で も限界值とされている $12,300 \mathrm{kWh} / \mathrm{t}$ を達成することは可能と 考えられる。

\section{5. 結言}

日本に抢けるアルミニウム製鍊は電力費の高騰により, 国際競 争力を失つてきていることは認めざるを得ない。しかしながら，
その苦境によつて得られている省エネルギー技術が発展すること は, 電力費の安い立地で生産性向上に力点を置いている世界のア ルミニウム製鍊界の技術的なリーダとなり得る要素を持つている。 世界のアルミニウム製鍊の生産能力は共産圈も含め1979年で約 1,700 万 $\mathrm{t} /$ 年と言われておりり, これに要する電力量は実に午間 約 $2 \times 10^{11} \mathrm{kWh}$ にもおよぶことになる。石油, 石炭等の資源の 節約時代に入つてきておりり,ソフトエネルギーパス提唱等に代表 される原子力発電拡大の困難さ, ソフトエネルギー自体の開発の 困難さの実情から, 生産性向上指向のアルミニウム製鍊への省エ ネルギー化の要求が強まることは必至であり, 省エネルギー技術 の花が開くときである。

\title{
Aluminium Smelting at Naoetsu Plant of Mitsubishi Light Metal Industries Ltd.
}

\author{
by Hisataka HOSOI
}

Our company, MLI, started aluminium smelting business at Naoetsu in 1963 and enlarged it to 4 potlines in 1970. Main raw materials for producing aluminium are alumina, carbon materials and fluorides. Alumina is reduced by electric power to aluminium in the molten bath of cryolite and aluminium fluoride at about $970^{\circ} \mathrm{C}$. Our technoloty is as follows:

(1) We have our own power station operated by using heavy oil. The power station is consisted of direct current generators driven by diesel type engines. This method is superior with respect to energy efficiency and facility utilization to the large unit steam driven power stations.

(2) We have 100kA Söderberg cells of vertical spike type. We have improved cathode lining technique, anode manufacturing process and have developed the computer control system of cell operation. Now our operational results have approached near those of Pre-baked type cells, with DC power consumption under $14,000 \mathrm{kWh} / \mathrm{t}-\mathrm{Al}$ and anode paste consumption under $500 \mathrm{~kg} / \mathrm{t}$-Al. And we have achieved DC power consumption of $13,000 \mathrm{kWh} / \mathrm{t}-\mathrm{Al}$ in several
cells.

(3) We have improved our original fluoride recovery technology to produce aluminium fluorides directly by using alumite sludge.

\section{〔3-10]東予製造所におけるプリベーク式アルミニウム製鍊}

牧武 ${ }^{1}$ 平沢 一 彦 $^{2}$

\section{1. 緒言}

住友アルミニウム製鍊株式会社は, 昭和 9 年に設 立された菊本製造所でアルミニウム製鍊を開始して 以来, 昭和 36 年に名古屋製造所 (年産能力 $50,000 \mathrm{t}$ 名古屋市) , 昭和 42 年に磯浦工場 (年産能力 75,000 t 新居浜市) , 昭和 45 年に富山製造所 ( 年産能力 168 , $000 \mathrm{t}$ 新湊市) とアルミニウム事業の拡充をはかつ てきたが, 将来の展望に立つてさらに大規模なアルミニウム製鍊 工場をつくる必要が生じ, 愛瑗県東予市に東予製造所 ( 年産能力 100,000 t ) を建設した。

以下, 世界のアルミニウム製鍊工業扔よび当社のアルミニウム 製鍊工業の沿革, 東予製造所の工場概要, 今後の展望について紹 介する。

\section{2. 沿革}

\section{$2 \cdot 1$ 世界のアルミニウム製錬工業}

1807 年にH. Davyが元素としてのアルミニウムを確認して以

1. 住友アルミニウム製鍊株式会社東予製造所製造部長 ( 現P.T.インド ネシアアサハンアルミニウム製鍊工場建設事務所技術部長 )

2. 住友アルミニウム製鍊株式会社東予製造所技術部長

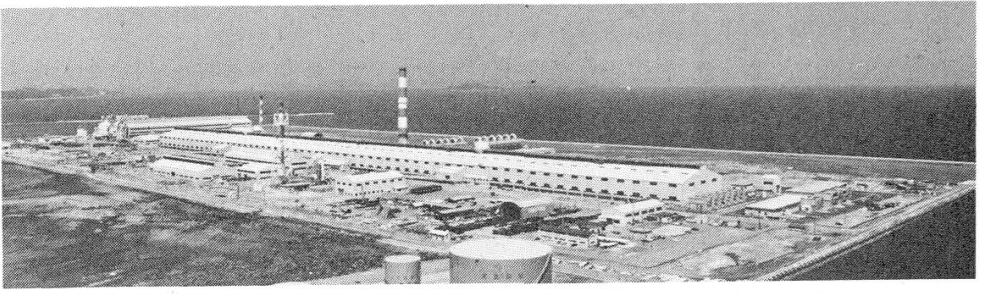

第 1 図 東予製造所全景

来, アルミニウムの製造法は各種試みられたが, 工業的には 1886 年アメリカのC.M. Hall お方びフランスのP. L. Héroultがア ルミナを溶融水晶石中に投入し炭素電極で電気分解を行なつてア ルミニウムを製造することに成功した。これがいわゆるホール． エルー（Hall - Héroult）法である。

初期の装置の構造は鉄製の鍋状の槽の内側に炭素をカソードと して張り付け，それに炭素アノードを吊り下げたものであつた。 アノードはあらかじめ焼成された炭素質で, 電解につれて消耗す ると交换する現在のプリベーク方式と同じ原理であつた。

その後電解炉の改良が進んだが， $1924 〜 25$ 年にゼーダベルグ 式アノードが電解炉に採用されたことによつてはじめて大きな変 革をみた。この方式はあらかじめ混揘した炭素材ペーストをケー シングの上部に投入し，下降するにしたがつて電解炉の熱により 
焼成しアノードとして使用するものである。当初はペグ（導電捧） を横から打ち込む横型ゼーダベルグ式電解炬であり, ペグを打ち 込む長さなど設計上の問題および作業上の問題のため炉の大きさ が制限され，現在の水準でも $130 \mathrm{kA}$ 程度が工業化の限度である。 次に現われたのは縦型ゼーダベルグ式電解炉である。この方式は アノードに打ち込んだ垂直ベグがフノードブスハーーにクランブされ てアノードを支えるので, 電解炉の大型化が可能となり, ゼーダ ベルグ式電解炉の隆盛時代をむかえた。

さらに最近では再びプリベーク式電解炉が注目をあびるように なり，ゼーダベルク式電解炬と勢力を 2 分する形となつている。 プリベーク式電解炬はアノード製造技術の進歩, アノード操作の 機械化などにより電力とアノードの消費减, 工数削減などを目的 としてゼーダベルグ式電解炉より一層大型の炉を目ざしており， $180 \mathrm{kA}$ 程度までが実用化されてきている。

$2 \cdot 2$ 当社のアルミニウム製錬工業

わが国のアルミニウム製鍊工業はホール・エルー法の発明から 遅れること約 50 年後すなわち昭和 9 年に昭和電工 (株)によつて開 始されているが, 当社は愛媛県新居浜市に第 1 番目の工場として 菊本製造所を建設し昭和11年にアルミニウムの生産を開始した。 当初は $15 \mathrm{kA}$ プリベーク式電解炉が設置されていた。その後, 当 時の軍事資材としてのアルミニウムの増産要請に応えるべく, 横 型ゼーダベルグ方式の技術を導入し，24kA， $30 \mathrm{kA}$ 横型ゼーダ ベルグ式電解炬を増設した。さらに菊本製造所は, $50 \mathrm{kA}$ 縦型ゼ 一ダベルグ式電解炉へと発展し, 能力の増強を実施した。このよ うにわが国のアルミニウム生産量は, 満州, 支那事変, 第 2 次世 界大戦を背景に急増していつた。

しかし, 終戦とともに軍需に支えられて発展していつたわが国 の製鍊業界は大きな打撃を被り，さらに占領軍統一司令部からの アルミニウム生産停止命令が追い打ちをかけた。その後, 昭和 20 年末にアルミニウムの生産の再開が許可され, 昭和 23 年にボーキ サイトの輸入を再開し, 日本のアルミニウム産業は軍需産業から 平和産業へと再出発をすることになつた。

昭和 30 年代に入り, 景気の上昇と経済基盤の払大により工業部 門の需要が大幅に伸長した。アルミニウムについても例外ではな く, この需要に対処するため, フランスのペシネー社より大型の 縦型ゼーダベルグ方式の技術を導入し, 当社は第 2 の工場として 名古屋市に名古屋製造所を建設した。名古屋製造所には $100 \mathrm{kA}$ 縦型ゼーダベルグ式電解炬が新設され昭和36年から稼動に入つた が，隣接の住友軽金属(株)に対してわが国最初の溶湯を直接供給 するホットチャージ方式を確立した。

また, 昭和 40 年代に入ると建設関係の好調, 特にアルミニウム サッシの需要が急増した。こうした状況に対応して, 当社は第 3 の工場として新居浜市磯浦に磯浦工場を建設した。磯浦工場には $100 \mathrm{kA}$ 縱型ゼーダパルグ式電解炬が新設され, 昭和 42 年から稼 動し始めた。

さらにアルミニウムの需要は伸び, 当社は第 4 の工場として富 山県新凑市に富山製造所を建設した。富山製造所には $100 \mathrm{kA}$ 縦 型ゼーダベルグ式電解炉が新設され昭和 45 年から稼動し始めた。

当社は 4 つの工場を建設するたびに，ゼーダベルグ方式の技術 的改良を進め, 斬新なアノードペーストの開発とカソード構造の 改良とにより，アノードトラブルの根絶と電力消費量の低減とに 成功した。電解操業については機械化とコンピュータによる自動 化を行ない，他方，環境保全についてもフッ化物ガスの捕集技術 の確立によつて大気中への排出量は著しく減少した。この結果, 電解電力は $14,000 \mathrm{kWh} / \mathrm{t}-\mathrm{Al}$ 程度, 炬命は 2,500 日以上に達 するに至つた。
当社はこのように長い経験をもつゼーダベルグ方式での実績を 基本としながら，さらに経済的な技術を追求した。その考え方は， 省エネルギー, 省資源, 省力化の実現にあり, 電流の強度ファク タとスケールファクタとの詳細な評価が基本である。最適条件は 製鍊工場の立地状況などの背景によつて変わるが, 当社の第 5 の 工場建設計画では, $150 \mathrm{kA}$ 以上のプリベーク式電解炉が従来の ゼーダベルグ式電解炬に対して有利と判断された。そこで, 当社 は技術開発の重点を「プリベーク式大型電解炬の開発」に置き, 電流密度, 電磁力, 熱バランス, 省力化および環境保全等の条件 を考慮して, 名古屋, 富山製造所での大型試験炉を通じて操業技 術を確立し, 第 5 の工場である東予製造所で実用化することにな つた。

昭和 48 年 6 月, 当社は愛媛県東予市に $175 \mathrm{kA}$ プリベーク式大 型電解炉を設置すべく建設に取りかかつた。しかし, 昭和48年末 の石油ショックにより日本経済は不況に落ち込みアルミニウム業 界は減産体制を余儀なくされ, 当社においては老朽化した菊本製 造所の電解炬の廃棄を決め, 昭和 49 年秋にはほぼ完成を見た東予 製造所もなかなか稼動できない状態であつた。こうした中で東予 製造所は昭和 50 年 4 月に操業を開始したわけであるが, 長引くア ルミニウム製鍊業界の不況によりなかなか増炉することができな かつたが，昭和54年10月に至つて I 期 220 炉全面稼動体制となつ た。

$$
\text { 3. 工 場 概 要 }{ }^{1)} \text { 2) 3) }
$$

$3 \cdot 1$ 立 地

東予製造所の立地する東予市臨海工業地帯は, 当社の主力工場 のある新居浜市から陸上約 $25 \mathrm{~km}$ ，海上では目と鼻の先の位置に あり，大きくみれば工業運河と呼ばれる瀬戸内海のほぼ中央に位 置し海上輸送の便がよく, 昭和39年 1 月に東予市が新産業都市の 指定を受けて以来, 最大の工業開発拠点として注目をあびている。 第 2 図に東予製造所位置図を示す。

また，新全国総合開発計画において，新しいネットワークの形 成が強調されているなかで, 本州四国連絡橋として, 神戸”鳴門 間, 児島一坂出間, 今治一尾道間の架橋が推進されており, なか でも今治一尾道間の連絡橋は, 東予市周辺の臨海工業地帯に隣接 して架橋されることになるためこの地区にとつては多大の架橋効 果をおよぼし，本州と一体となつて発展が予想される。

当社が東予市に進出することになつたのは，次の理由による。

（i）東予市の臨海工業地帯は, 新産業都市として港湾道路が 整備され，かつ必要な面積の用地が得られた。

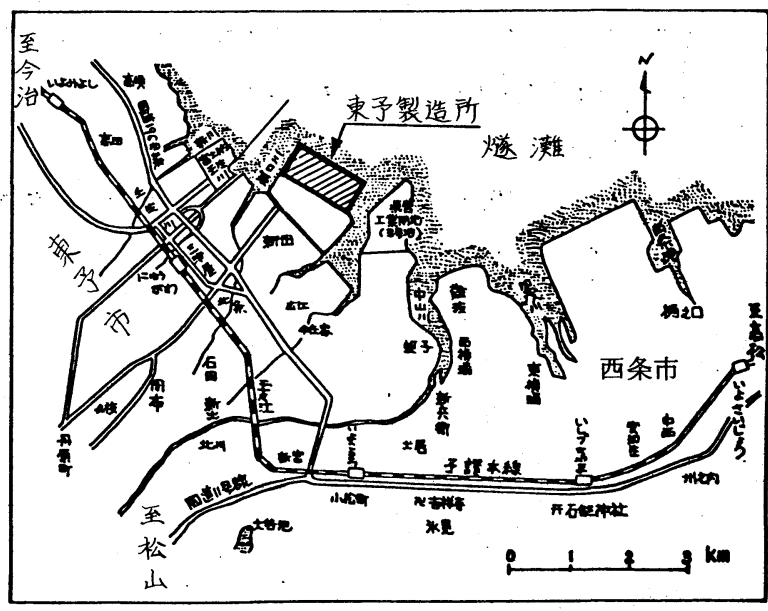

第2図東予製造所位置図 
（ii）当用地は, 大規模な公共埠頭が隣接し, 幹線道路も至近 距離にあり，海上・陸上運輸に便利である。

（iii）東予地区は, 当社の既存の新居浜地区に近く, 原料・労 働力等の点でその事業基盤を活用することか゚できる。

(iv) 隣接干拓地の確保により関連産業の誘地も可能であり, 製鍊一加工ラインの強化により，相互に国際競争力を強化しうる。

（V）アルミニウム製鍊に必要な電解電力については, 住友共 同電力 (株) 壬生川火力発電所を隣接地に建設し, 所要電力の確保 が可能である。

\section{$3 \cdot 2$ 規 模}

当所は I 期計画設備の建設を終光現在操業中であり, 生産能力 は年産 100,000 t である。レイアウト上II 期および正期の增設によ $\eta$, 最終的には年産 $300,000 \mathrm{t}$ 能力の設備が建設可能である。敷 地面積は約 $740,000 \mathrm{~m}^{2}$ であり, 将来加工丁場の進出が予定されて いる隣接地も合わせると約 $1,350,000 \mathrm{~m}^{2}$ となる。従業員数は現在, 約 380 名である。

\section{$3 \cdot 3$ 採用技術}

当社独自の技術によるプリベーク式電解炬を採用し，原単位の 向上, 設備費の削減および機械化・自動化・計装化による省力化 をはかつた。

当所の特長注次のと扔りである。

（i）電流容量 大型炬に適した導体配置, カソード構造な どの技術開発により，電磁力をはじめとする諸問題を解決し，175 kA という大電流容量炉の実用化を果した。大型炉のため設供費, 生産性などの点で有利である。

（ii）電力原単位熱バランスの良好なカンード構造, 適正 な導体配置およびコンピュータ制御の導入等により，大型炉なが ら安定的に操業されており，良好な電力原単位で推移している。

（iii）炉命当社と協和カーボン(株)で共同開発した特殊ブ ロック（ S K ブロック）の採用ならびにカッード構造の改良によ り長炉命が期待されている。

（iv）省力化電解工場および電極工場では, 多目的特殊 ク レーンを設置し諸作業の機械化をはかつている。また，電解炉の 制御にはプロセスコンピュータを導入し操業を自動化している。

（V）環境対策 プリベーク方式の採用により電解炉には密 閉式フードが設置されており，炬から発生するガスは高効率で捕 集できるので，天井から排出されるガスはきわめて少なく建家内

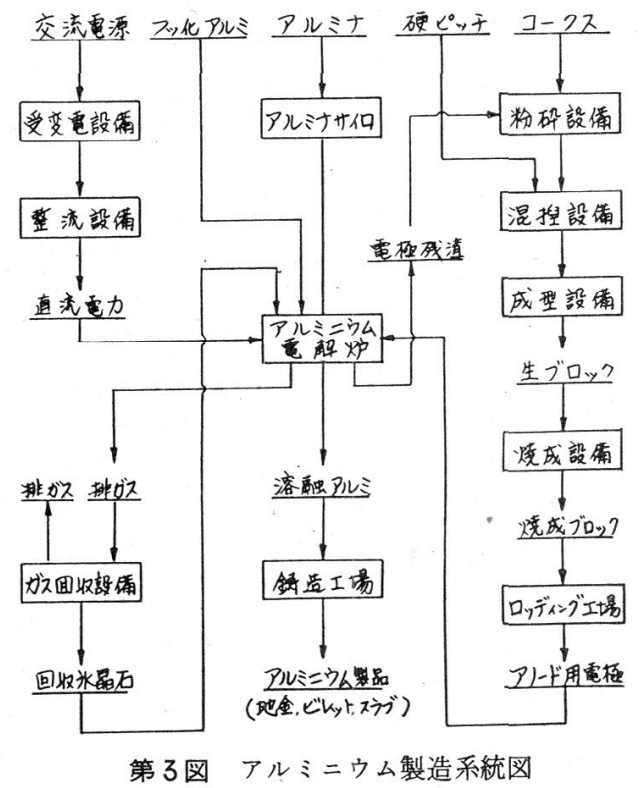

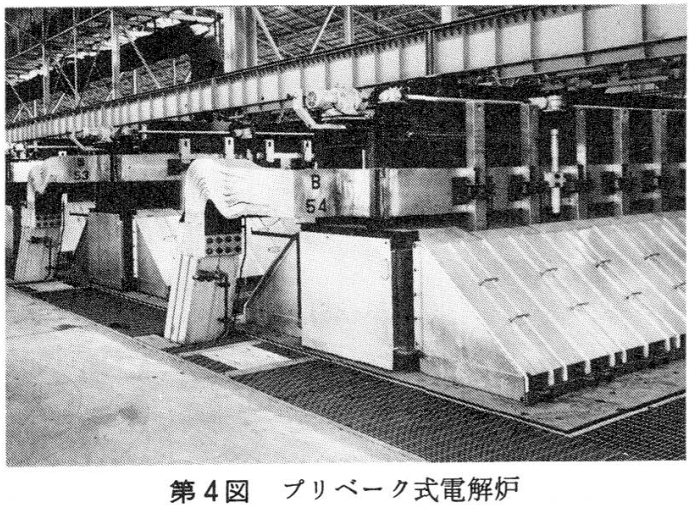

の作業環境も優れている。

$3 \cdot 4$ プロセスの説明

第 3 図にアルミニウムの製造系統を示す。

当所は, 電解工場を中心に電極工場, 鋳造工場, ガス回収設備,

受配電設備，原材料荷役設備などから成つている。

以下, 各工場について工程の概要を中心に述べる。

3・4・1 電解工場 電解工場では, 原料のアルミナを約 $960^{\circ} \mathrm{C}$ で溶融した氷晶石浴中に溶解させて, 電気分解によりアル ミニウムを製造する。電解工場は, 幅約 $50 \mathrm{~m}$, 長さ約 $800 \mathrm{~m}$ とい う巨大なもので, この中に $175 \mathrm{kA}$ プリベーク式電解炉 220 炉が, サイド・バイ・サイドに 110 炉ごと，2 列に設置されている。 第 4 図に電解炬外観を示す。

原料のアルミナは, 輸入サンディアルミナおよび当社菊本製造 所で生産したフラワリーアルミナを用い, ガス回収設備で回収し たダスト, 承晶石等とあらかじめ混合して電解工場上部に設置さ れたアルミナビンに輸送される。このアルミナは次に多目的特殊 クレーンに設置されたホッパヘ装入され，1日1回クレーンから 電解炉のホッパへ配給される。配給されたアルミナは，炉に装着 されたクラスト破砕機により定期的にクラストを破砕して電解浴 中に装入される。電解浴は, 氷晶石をべースとしフッ化アルミニ ウム，フッ化カルシウムを添加したものである。

アルミニウムの生成反応に関しては種々の反応式が提唱されて いるが，マクロ的には下記の反応によりアルミニウムが析出する。

$2 \mathrm{Al}_{2} \mathrm{O}_{3}+3 \mathrm{C} \rightarrow 4 \mathrm{Al}+3 \mathrm{CO}_{2}$ (1)

炬底に析出した溶融了ルミニウムは, 多目的特殊クレーンに装着 された真空レードルにより各炉とも 1 日 1 回の頻度でくみ取られ る。くみ取られた溶融アルミニウムは運搬車により鋳造工場へ送 られる。

一方, 電解用陽極として使用するアノードブロックは, 電解反 応により徐々に消耗するので, 所定のサイクルで多目的特殊クレ ーンにより新しいアノードと取り替える。取り出されたアノード は，アノード運搬車によりロッディング工場へ送られる。

また, 各炉ごとの定期的なクラスト破碎, アルミナの浴中への 装入, 陽極効果の処理および炉電圧の調整は, すべてコンピニー タにより制御されており徹底した省力化がはかられている。

$3 \cdot 4 \cdot 2$ 電極工場 電極工場では, ゼーダベルグ時代から 培つた経験に加え, ブロック製造試験を通じて開発した世界最大 の大型プロックを製造している。当工場は混捏・成型をおこなう 成型工場, ブロックの焼成を受け持つ焼成工場および道電棒を接 続するロッディング工場の 3 工程で成つている。

以下, 工場別に工程の概要を述べる。

（1）成型工場 本工程では, コークス, 硬ピッチおよび電 解工場で使用されたアノード返り材を原料として生ブロックを製 
造する。成型工場は, 高さ約 $30 \mathrm{~m}$ の 8 階建て構造で, その中にふ るい分け機, 破碎機, 混捏機㧍よび成型機等が立体的に配置され ている。

主原料のコークスは, サイロから抜き取られ成型工場の最上階 までバケットェレベータによつて運ばれ, 重力を利用してふるい 分けされた後, 粒度別に貯蔵される。一方, ふるい上の粗いコ一 クスはクラッシャにて破砕後, 再びふるい分け機にかけられる。 また, 整粒されたコークスの一部はボールミルで微粉砕し微粉原 料とする。硬ピッチは倉庫から取り出され破砕, 乾燥されビンに 貯蔵される。使用済アノードの返り材も破砕後, ふるい分けされ てからビンに貯蔵される。

次に, 所定の粒度配合比で各々のビンから原料を抜き取り, 予 熱した後, 混捏機に送りアノードペーストを製造する。混捏機は 連続方式を採用することにより，均一で高品質のペーストを得る ことが可能である。アノードペーストは秤量後, 振動式成型機に かけられ, 所定形状の生ブロックに成型される。成型された生ブ ロックは, 冷却設備を通り計量された後, 貯蔵建家へ運ばれる。

（2）焼成工場 本工程では, 生ブロックを約 $1,200^{\circ} \mathrm{C}$ で焼 成し既焼成ブロックを製造する。焼成炉は密閉型リングファーネ スを採用し，均一な炬内温度分布と良好な作業環境が達成された。 また, 多目的特殊クレーンの採用により作業の大幅な省力化が可 能となつた。

生ブロックは，貯蔵建家からブロック搬送設備を経て受け入れ， 多目的特殊クレーンで焼成炬内に順次装入される。同時に, 充填 用ュークスでブロック間を充填し, 最上部にはブロック酸化防止 のため耐火物ボールが装入される。このようにして生ブロックが 炬内に装入された後, 炬カバーを設置し焼成が開始される。焼成 は重油バーナにより所定の温度曲線にしたがつて行なわれる。焼 成が完了すれば炉内でブロックを冷却した後, 炉カバーを取りは ずし耐火物ボール，充填用コークスを順次吸引排出しブロックを 取り出す。これらの作業はすべて多目的特殊クレーンで逐行され る。取り出されたブロックはブロック搬送設備で貯蔵建家へ送ら れる。

また，焼成中に発生するガスは，排ガス処理設備へ導かれ，イ オウ酸化物やピッチ分を吸収した後, 煙突から排出される。回収 されたピッチは焼成炉で燃料として再利用する。

（3）ロッディング工場本工程では, 既焼成ブロックに導 電棒を接続し, 表面に酸化防止のためアルミニウムコーティンク を施した後, 電解工場へ供給する。また, 電解工場での使用済ア ノードを処理し導電棒等を回収する。ロッディング工場内では新 アノード, 使用済アノードおよび導電棒の移動がすべてパワーア ンドフリーコンベヤによつて行なわれ, 各処理はこのコンべヤに 沿つて平面的に配置された各機器により連続的に行なわれる。

貯蔵建家から受入れた既焼成プロックは，溶融鋳鉄の鋳込みに より導電棒が接続される。鋳込み済ブロックは, その表面にアル ミニウムコーティングが施された後, アノード運搬車で電解工場 へ送られる。一方, 電解工場で使用されたアノードは, 同じ運搬 車でロッディング工場へ送り返され, クラスト除去, 導電棒の除 去ならびに接続用鋳鉄の除去が行なわれる。回収された導電棒は 寸法検査の後, 清摩され再使用される。また, クラスト, 使用済 ブロックおよび接続用鋯鉄も各々回収され循環使用される。

$3 \cdot 4 \cdot 3$ 鋳造工場 鋳造工場では, 電解炉で析出した溶融 アルミニウムを主原料とし，さらに鋳造工場で発生したスクラッ プおよび製品品質上, 必要な金属元素を添加しアルミニウム製品 を鋳造する。当工場では，真空炉や連続均質化炉の採用により品 質向上と同時に大幅な省力化をはかつている。
主原料の溶融アルミニウムは, 電解工場から溶湯運搬車で直接 鋳造工場へ運ばれる。炬への装入は真空レードルを片吊り傾転し 唃を使つて行なう。炉に装入された溶融アルミニウムは, フラッ クス処理の後, 所定の温度で保持され非金属介在物を浮上分離さ れる。鋳造前に非金属介在物を炬から搔き出し鋳造温度に保持す る。

以下，製品ごとに鋳造操作の概要を記述する。

（1）地金炬を傾転し供給された溶融アルミニウムは，桶， 注湯機を経て鋳造機へ送られる。鋳造機はコンベヤ式水冷鋳造機 を採用している。コンベヤに装着された鋳型内へ一定量ごと注湯 した後，表面に浮上した涬を蛍き取り水冷により強制凝固させる。 凝固した地金は, 自動積付機で所定の荷姿に積み付けられりフト により製品置場に搬出される。

（2）ビレット ビレットの鋳造には縦型半連続鋳造機を採 用している。炉を傾転し供給された溶融アルミニウムは, 䇶およ び鋳造機上部へ設置された分配鍋を経て鋳型内へ注湯される。鋳 型は水冷方式となつており凝固速度に合わせてフロートで溶湯の 流量制御を行ない, ビレットの支持台を降下させながら鋳造を行 なう。鋳造終了後, 上部の分配鍋, 鋳型台を撤去してクレーンに よりビレットを吊出す。吊出されたビレットは搬送設備により連 続的に均質化炬へ送り込まれる。均質化炉はウォーキングビーム による連続方式を採用し, 輸送の合理化, 均質化処理時の温度分 布の均一化をはかつている。均質化炬から出てきたビレットはあ らかじめ空冷された後水冷され, 切断機で所定の長さに切断され てから棝包され製品となる。

（3） スラブ スラブは板などの圧延用素材であるため, 不 純物やガスの含有は製品に致命的な影響を与える。したがつて, 保持炬から供給された溶融アルミニウムはまず, 真空炉へ送られ 脱ガス処理が施される。脱ガス後, さらにフィルタにかけられ不 純物の除去がなされた後, 鋳造機へ送られる。鋳造機は大型スラ ブの製造に適した半連続鋳造方式を採用している。鋳造終了後は ビレットと同様にクレーンで吊出され製品置場へ送られる。

$3 \cdot 4 \cdot 4$ ガス回収設備 本プロセスでは, 電解炉から発生 する排ガス中に含まれるフッ素分を処理し公害防止をはかるとと もに, フッ素分を氷晶石として固定し再利用を行なう。プリベー ク式電解炬の採用により電解炉の密閉化が可能なため, 発生源で のガス捕集効率はきわめて高く環境濃度を支配する天井からの排 出量は大幅に削減されている。

電解炬から発生する排ガスは, 炬に取り付けられたフードで集 められダクトを通じてブロアーで吸引される。吸引された排ガス は電気集塵機で除鹿後, 洗浄塔に導かれてアルカリ夜で洗浄され る。アルカリ夜で洗浄された排ガスは，ミスト分離機でミストを 分離した後, 清浄ガスとして煙突より放出される。一方, アノー ド交換作業時に炬から一部洩れた排ガスは, 電解建家天井に設置 された洗浄設備によりアルカリ液で洗浄される。

アルカリ液に吸収されたフッ化物は下記の反応により氷晶石に 合成される。

$6 \mathrm{HF}+2 \mathrm{NaOH}+\mathrm{Na} \mathrm{AlO}_{2} \rightarrow \mathrm{Na}_{3} \mathrm{AlF}_{6}+4 \mathrm{H}_{2} \mathrm{O} \cdots \cdots$ (2) 合成された氷晶石は沈降, 洰過後, 焙焼工程へ送られ口ータリ一 キルンにて婄焼された後, 溶剤混合設備へ送られる。電気集塵機 で捕集されたダストも同様に溶剤混合設備へ送られ, アルミナ等 と混合された後, 電解炉で再使用される。

$3 \cdot 4 \cdot 5$ 受配電設備 本プロセスは, 受変電整流設備およ び配電設備から成り，隣接して設置された住友共同電力(株)壬生 川火力発電所から $187 \mathrm{kV}$ で受電した後適当な電圧, 電流に变換 して電解工場およびその他の各ブラントへ電力を供給するもので 
ある。停電はアルミニウム製鍊工場にとつては致命的な影響を与 えるため, 信頼性の高い設備を採用し，完壁な保全体制をしいて 対処している。

3・4・6 原材料荷役設備 アルミナは当社菊本製造所のフラワ リーアルミナおよび輸入サンディアルミナを使用しているが，ど ちらも菊本製造所を拠点として海上輸送を行なつている。電極用 原料としてのコークス, 硬ピッチならびに電解浴原料としてのフ ッ化物などについても，瀬戸内海の海上輸送を活用して搬入して いる。荷役作業は真空吸引式アンローダとそれに続くコンベヤラ インにより大幅な省力化が達成されている。

$$
\text { 4. 今後の展望 }{ }^{4) \sim 9)}
$$

石油火力に依存しているわが国のアルミニウム製鍊業界は，石 油価格の高騰, すなわち電力価格の高騰により減産を強られ昭和 53年の産業構造審議会・アルミニウム部会によつて答申されたご とく，わが国のアルミニウム製鍊能力年産 164 万 $\mathrm{t}$ を 110 万 $\mathrm{t}$ に 縮小することを余儀なくされている。

したがつて，わが国のアルミニウム製鍊業界は生き残るために 電力原単位を最重点に省エネルギー, 省力化, 省資源により技術 的な優位を保つことが至上命令となつており，一方，技術輸出を 含む資本参加によつて海外への発展がアルミニウム製鍊業界に課 せられた命題である。

当社においては，ゼーダベルグ技術を国内はもとより，アルコ アをはじめとする世界10数社に供与している。また，プリベーク 技術も，すでに国内においては住軽アルミニウム工業 (株)酒田工 場に供与し，海外に捛いてはインドネシアのアサハン計画および オーストラリアのグラッドストーン計画に供与している。

アサハン計画においては, 当社で設計, 建設および操業指導を 担当し, 操業指導ではピーク時に63名, 延べ86名のインドネシア 研修生が当所で技術習得のため実習を行なつた。またグラッドスト 一ン計画においても, 当所がノウハウの伝達および操業指導を担 当することになつており，すでに先方のエンジニアが数回にわた つて来所し，当所において実習も行なつた。さらに，このブリべ 一ク技術はその他の製鍊計画においても海外他社から数多くの引 き合いが寄せられている。このように東予製造所は，当社のプリべー ク技術のセンターであり，さらに海外に対する基盤を担つている。 一方, 技術開発においては現行ホール・エルー法の改良・改善
第1表 現行法における省エネルギー対策

\begin{tabular}{|c|c|c|}
\hline 項 & 題 & 対 \\
\hline 1. 電磁力 & $\begin{array}{l}\text { フレミングの法則に起 } \\
\text { 因するたソード界面の } \\
\text { 摇動および隆起 }\end{array}$ & 導体配置の改良 \\
\hline 2. 熱バランス & $\begin{array}{l}\text { (1)炬体からの熱放散 } \\
\text { (2)適正な極間距離の確 } \\
\text { 保 }\end{array}$ & $\begin{array}{l}\text { (1)材質を含めたカソー } \\
\text { ド構造の改良 } \\
\text { (2)最適電流密度とクラ } \\
\text { スト形状の検討 }\end{array}$ \\
\hline $\begin{array}{l}\text { 3. プロセス. } \\
\text { コントロール }\end{array}$ & $\begin{array}{l}\text { (1)カソード界面の摇動 } \\
\text { (2)浴中アルミナ濃度の } \\
\text { 変動 }\end{array}$ & $\begin{array}{l}\text { (1) コンピュータ制御に } \\
\text { よる電圧振動の防除 } \\
\text { (2)コンピ=ータ制御に } \\
\text { よる最適装入方法の } \\
\text { 確立 }\end{array}$ \\
\hline
\end{tabular}

が今後の課題である。ホール・エルー法の技術は現在, 直流電力 原単位が $13,500 \sim 14,000 \mathrm{kWh} / \mathrm{t}-\mathrm{Al}$ であり, その工業的限界 値は $12,300 \mathrm{kWh} / \mathrm{t}-\mathrm{A} 1$ 程度といわれている。当所では, 現在 の技術を工業的限界值に近づけるために第 1 表に示す項目につい て開発の重点を置き努力をしている。

\section{5. 結言}

以上, 東予製造所の概要と置かれている立場について記載した が，このような事態に直面しているわが国のアルミニウム業界に おいて我々がやらねばならないことは余りにも多い。さらに努力 を積み重ねて技術開発と海外への発展に励みたい所存であるが， 今後一層のご指導とご鞭撻を扔願いする次第である。

\section{参 考 文 献}

1） $\mathrm{Al}$ 一ある, [3], 50〜 52, (1975)

2）住友化学誌, [特. I ] , 53〜 55, (1975)

3) $\mathrm{OHM}, 62[7], 42 \sim 43,(1975)$

4）池田八郎：化学と工業, 23 [8]，1045 1049, (1968)

5) 松尾吉郎：燃料協会誌, 50 [525], $8 \sim 20,(1971)$

6）阿部方朋 - 平沢一彦・柴田潔：住友化学誌, [特. II], $1 \sim 17,(1975)$

7）增子昇・高橋正雄：軽金属, $26[10], 531 \sim 536 ，(1976)$

8）アルミニウム新製鍊技術委員会：アルミニウムの新製鍊技 術報告書, (1976)

9）塩谷茂夫：アルトピア，7[7]，9～20，（1977）

\title{
Smelting of Aluminium by Prebaked Anode Pots at Toyo Works
}

\author{
by Takeru MAKI and Kazuhiko HIRASAWA
}

Sumitomo Aluminium Smelting Co., Ltd. started producing aluminium by Prebaked anode pots of $15 \mathrm{kA}$ current load at Niihama in 1936. As per the worldwide trend of the industry, Sumitomo extended the pot design to 30 kA horizontal stud Soederberg pots, which were followed by $50 \mathrm{kA}$ vertical stud Soederberg pots. In 1961, a smelter was constructed at Nagoya by using $100 \mathrm{kA}$ vertical stud Soederberg pots, and two smelters with same pots were built in Niihama and in Toyama.

Supported by years of experience in operation of $100 \mathrm{kA}$ vertical stud Soederberg pots, Sumitomo worked hard in development of better technology. The comparative study of the intensity factor of current and the scale factor, was directed to satisfy the requirements of industry, like engergy saving, labour saving, and environmental pollution control. Curtailment of energy consumption was studied by means of i) optimum current density, ii) suppression of effect of electromagnetic force by intervenient influence between flows of electrolysis current and bus bar current, and iii) cathode construction of good heat balance. Reduction of labour requirement was dependent on process control by computer, and improvement to environmental pollution was attributable to scrubbing of both the primary pot gas and the secondary gas from the potroom building.

Outcome of Sumitomo's development works was incorporated in a 100,000 mtpa aluminium smelter equipped with $175 \mathrm{kA}$ prebaked anode pots, which was built in 1973 at Toyo City.

After being put into operation in 1975, the modern smelter is now running at full production capacity. 